\title{
Freeze-Drying of Sweet Peppers
}

\author{
M. A. González, E. Diaz Negrón, H. Cancel, and A. C. Rivera ${ }^{1}$
}

\section{INTRODUCTION}

A variety of garden peppers known in Puerto Rico as sweet peppers (aj₹ dulce), is widely used fresh as a condiment. Although considerable confusion exists as to exact botanical classification $(1,2,3)^{2}$ these peppers generally are related to the species Capsicum frutescens.

These peppers, as well as all Capsicums (4), include fruits with a wide range of sizes, shapes, and flavors. They are mildly pungent and have a very rich aroma.

The fresh fruit is used whole, cut in halves or in pieces, to season foods in cookery and to flavor sauces. The green fruit usually is preferred over the ripe or red fruit.

Although sweet peppers are produced generally throughout the year, there are some periods when production is below demand and the price is high. There is a great surplus of fruit during other periods and the price subsequently is low. These studies were initiated to develop methods for sweet pepper preservation in an effort to have the fruit available throughout the year at a reasonable price, and to assure a steady farm income. The results of these studies are reported herein.

\section{REVIEW OF LITERATURE}

No investigations on dehydration of Puerto Rican sweet peppers are reported in the literature. Numerous publications are available, however, concerning the dehydration of other pepper species.

The effect of drying on initial color retention and pungency in red peppers has been discussed by Lease and Lease (5). Color retention of Capsicums has been investigated by Lease and Lease (6) and Moster and Prater ( 7 , 8 ). Zuzuki et al. ( 9 ) described a new method for determination of pungency in red peppers, while Wirth et al. (10) reported on the Scoville organoleptic method for evaluation of Capsicum. Lantz (11) found that slicing or slitting the pods of chili peppers reduced the drying time by half, with no loss of initial color when drying them for 72 hours at 140 to $168^{\circ} \mathrm{F}$. It has been the

1 Associate Food Technologist, former Research Assistant, Research Assistant, and Assistant Chemist, respectively, Agricultural Experiment Station, Mayagüez Campus, University of Puerto Rico, Rio Piedras, P.R. The authors wish to express their gratitude to R. Guadalupe, Assistant Horticulturist of this Station for the cooperation given in the field experiments, and to $\mathrm{D}$. Alcala, Associate Bacteriologist of this Station, who performed the bacteriological analyses.

2 Italic number in parentheses refer to Literature Cited, pp. 147-8. 
practice of pepper growers in South Carolina to dry the whole fruit at 120 to $180^{\circ} \mathrm{F}$, or a combination of temperatures within these ranges. A variation in color has been noted with higher drying temperatures (5).

Freeze-drying of foods has received much industrial recognition. Products commanding a premium price are being commercially freeze-dried. Such products can absorb the high cost of freeze-drying economically (12). Among the advantages commonly associated with the freeze-drying process are that more of the nutrients, taste, color, and constituents of flavor are retained than with any other industrial process (19).

The operations involved in freeze-dehydration of foods, in general, include the preparation of the food, freezing, dehydration, and packaging. The conditions under which these operations are performed influence not only the efficiency and cost of the process, but also the quality of the final product (14).

According to Larson et al. (15) food preservation by freeze-drying processes has been limited because of the high cost of equipment for a relatively low production rate due to the low drying rate. There are many variables that affect rate of drying during freeze drying. The influence of the raw material and some of the processing parameters on product quality and rates of freeze-drying has been studied by Goldblith et al. (16) and Lusk, et al. (17). Lusk et al. (17) indicate how the drying rate increases with increasing temperatures, while Goldblith et al. (16) state that the more severe the drying cycle, the greater the pigment oxidation in both freeze-dried shrimp and salmon. The pigment oxidation in those products is directly related to product quality in terms of consumer acceptability.

The temperature-time relationship in the normal freeze-dehydration process does not, in itself, result in substantial enzyme inactivation (16). Many types of foods are dehydrated without a preliminary enzyme inactivation heat treatment and low moisture content (16) is the only safeguard against subsequent enzymatic deterioration in storage of these products. Draudt et al. $(16,18)$ have found that enzymes, such as lipase in freeze-dried meat and polyphenolase in bananas, are active at a very low moisture content.

The microbial aspect of freeze-dried foods is of great importance from both the standpoint of food quality and public health. This aspect recently has received attention by Sinskey et al. (19) and Saleh et al. (20) who have shown that a number of test microorganisms in model systems and natural foods, and the flora in some foods, are capable of surviving freeze-drying.

Packaging materials for freeze-dried products must keep out water vapor and oxygen, and protect fragile items from being crushed (21). Ziemba (22) indicates the best packaging for freeze-dried items is a metal container or a special film pouch filled with an inert gas. Foda et al. (22) found that freeze- 
dried beans packed in metal containers generally were higher in quality than those packed in either polyethylene bags or paper cartons. Daout et al. (12) found the AFC pouch to be an excellent container to protect color, aroma, and flavor of freeze-dried red bell peppers. Deterioration of dehydrated vegetables has been characterized by the development of offflavor and loss of color. This deterioration is accelerated greatly during storage, particularly if the storage atmosphere contains oxygen (23). The storage stability of freeze-dried and conventionally dehydrated vegetables, stored in an oxygen-containing atmosphere, is questionable. It has been reported (23) that vegetables dried by sublimation are vastly more resistant to storage destruction than vegetables dried conventionally. In an investigation of freeze-dried carrots, Mackinney et al. (24) found freeze-dried carrots to be less stable under various storage conditions than carrots dried conventionally.

\section{MATERIALS AND METHODS}

The sweet peppers used in this study were obtained from an experimental plot grown in the Solis Farm in Río Piedras. The fruit was harvested fully developed, but still green, and ranged in size from 0.5 to 1.5 inches in length, and from 0.5 to 1.5 inches in width, with an average weight of $7.5 \mathrm{~g}$. Prior to dehydration, the peppers were washed in a rotary rod washer with tap water, then dehydrated whole, cut in halves, or slitted.

For freeze-drying studies, the fruit was frozen at $-20^{\circ} \mathrm{F}$. and dried in a Stokes freeze-drier model 004-17. The absolute pressure in the drying chamber was maintained at about $0.1 \mathrm{~mm}$. Hg. The temperature of the peppers during dehydration was measured with thermocouples. Platen temperatures of $200,180,165,150$, and $140^{\circ} \mathrm{F}$. were used in these studies.

Duplicate lots, using down flow air, with dry bulb at $165^{\circ} \mathrm{F}$. and wet bulb at $120^{\circ} \mathrm{F}$., were dried in a forced draft Proctor \& Schwartz dehydrator. Dehydrated and freeze-dried peppers were packed in glass jars and enameled tin cans, and stored at room temperature $\left(80\right.$ to $90^{\circ} \mathrm{F}$.). At regular intervals, samples were analyzed for moisture, color, ether extract, and volatile oils.

Moisture was determined by the vacuum-oven method (25). Color was measured using the Hunter Color and Color Difference Meter, calibrated with a green standard with $R d=25.0, a=-28.0$ and $b=+6.9$. For the ether extract determinations, the procedure delineated in the A.O.A.C. (25) was used.

For the volatile oils determinations, a $500 \mathrm{~g}$. fresh or $100 \mathrm{~g}$. dehydrated sweet pepper sample was weighed and homogenized with water in a blender.

a Trade names are used solely to provide specific information. This does not imply endorsement or recommendation by the Agricultural Experiment Station. 
It was then refluxed for 8 hours in the apparatus for volatile oils in spices (25). The recovered oils were extracted three times with petroleum and sulfuric ethers. These three portions were transferred to a previously weighed $20 \mathrm{ml}$. beaker. The ether was evaporated to dryness and the beaker was weighed after being left overnight in a dessicator. Volatile oils were calculated on a dry basis.

\section{RESULTS}

\section{EFFECT OF SAMPLE PREPARATION ON DRYING RATE AND}

QUALITY OF THE DEHYDRATED PRODUCT

The moisture content and color of fresh and dehydrated whole, cut, and slitted peppers are shown in table 1 for samples freeze-dried for 8.5 hours at

TABLE 1.-Color and moisture content of hot-air and freeze-dried sweet peppers

\begin{tabular}{|c|c|c|c|c|c|c|c|}
\hline \multirow{2}{*}{$\begin{array}{c}\text { Characteristics } \\
\text { measured }\end{array}$} & \multirow{2}{*}{ Fresh } & \multicolumn{2}{|c|}{ Half cut } & \multicolumn{2}{|c|}{ Whole slitted } & \multicolumn{2}{|c|}{ Whole } \\
\hline & & $\begin{array}{l}\text { Freeze- } \\
\text { dried }\end{array}$ & $\begin{array}{c}\text { Hot-air } \\
\text { dried }\end{array}$ & $\begin{array}{l}\text { Freeze- } \\
\text { dried }\end{array}$ & $\begin{array}{c}\text { Hot-air } \\
\text { dried }\end{array}$ & $\begin{array}{c}\text { Freeze- } \\
\text { dried }\end{array}$ & $\begin{array}{c}\text { Hot-air } \\
\text { dried }\end{array}$ \\
\hline $\begin{array}{l}\text { Moisture } \\
\quad \text { (percent) } \\
\text { Hunter color }\end{array}$ & 88.93 & 1.53 & 15.07 & 15.27 & 34.59 & 65.37 & 63.83 \\
\hline $\begin{array}{l}R d \\
a \\
b\end{array}$ & $\begin{array}{c}13.0 \\
-8.4 \\
+18.45\end{array}$ & $\begin{array}{r}37.5 \\
-17.0 \\
+25.2\end{array}$ & $\begin{array}{r}28.8 \\
-5.5 \\
+20.7\end{array}$ & $\begin{array}{r}35.3 \\
-17.5 \\
+25.0\end{array}$ & $\begin{array}{r}21.3 \\
-2.2 \\
+16.0\end{array}$ & $\begin{array}{r}23.5 \\
-5.7 \\
+20.1\end{array}$ & $\begin{array}{r}22.4 \\
-3.5 \\
+16.7\end{array}$ \\
\hline
\end{tabular}

a platen temperature of $165^{\circ} \mathrm{F}$. for 2.5 hours. The temperature was then lowered to $140^{\circ} \mathrm{F}$. during the rest of the drying cycle.

The moisture content of the half-cut peppers was reduced to 1.53 percent, which indicated that the samples were completely dehydrated during this cycle. The whole-slitted samples had a moisture content of 15.3 percent which indicated only partial drying for a freeze-dried product. Whole peppers failed to dry under these conditions. Similar effects in sample preparation were observed for the hot-air dehydration.

The heat penetration curves are shown in figure 1. Heat penetration was faster in the half-cut and whole with perforated skin peppers than in the whole fruit. However, the heat penetration curves indicated that the difference in drying rate cannot be attributed to the rate of heating, since the differences in the heat penetration curves are too small to be significant.

Sweet peppers have a tough, waxy skin or pericarp which makes it difficult for the moisture to transfer during dehydration. It was observed in the course of these studies that some whole peppers after the drying period were inflated with water; the skin was separated from the rest of the fruit 
and the space between was filled with water. When the skin was perforated and the fruit heated again, complete dehydration resulted.

In figure 2 the values of $\tan -1 a / b$ are plotted for fresh, freeze-dried

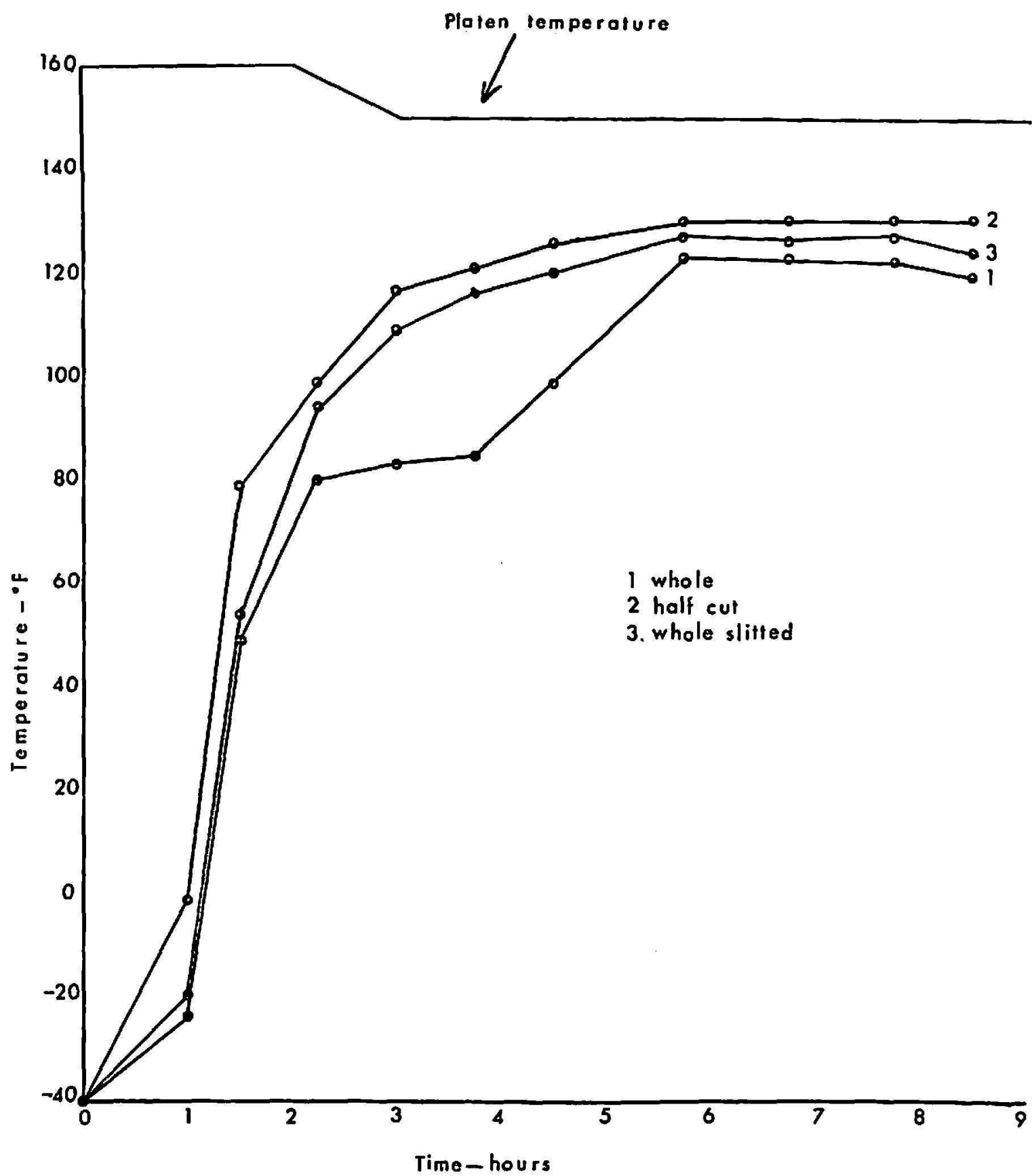

FIG. 1.-Time-temperature relationship during freeze-drying of whole, half-cut, and whole-slitted sweet peppers.

and hot-air dried peppers when $a$ and $b$ values were measured with the Hunter Color and Color Difference Meter. The results indicate there is a concentration of green color in half-cut and whole-slitted peppers during freeze-drying. 
In the whole freeze-dried peppers, there is a destruction of the green pigment similar to the one observed in conventionally hot-air dried peppers.

The results of these studies indicate that when preserving a mild, pungent fruit such as sweet peppers by dehydration, freeze-drying results in an end product that has better color and quality than obtained from hot-air dry-

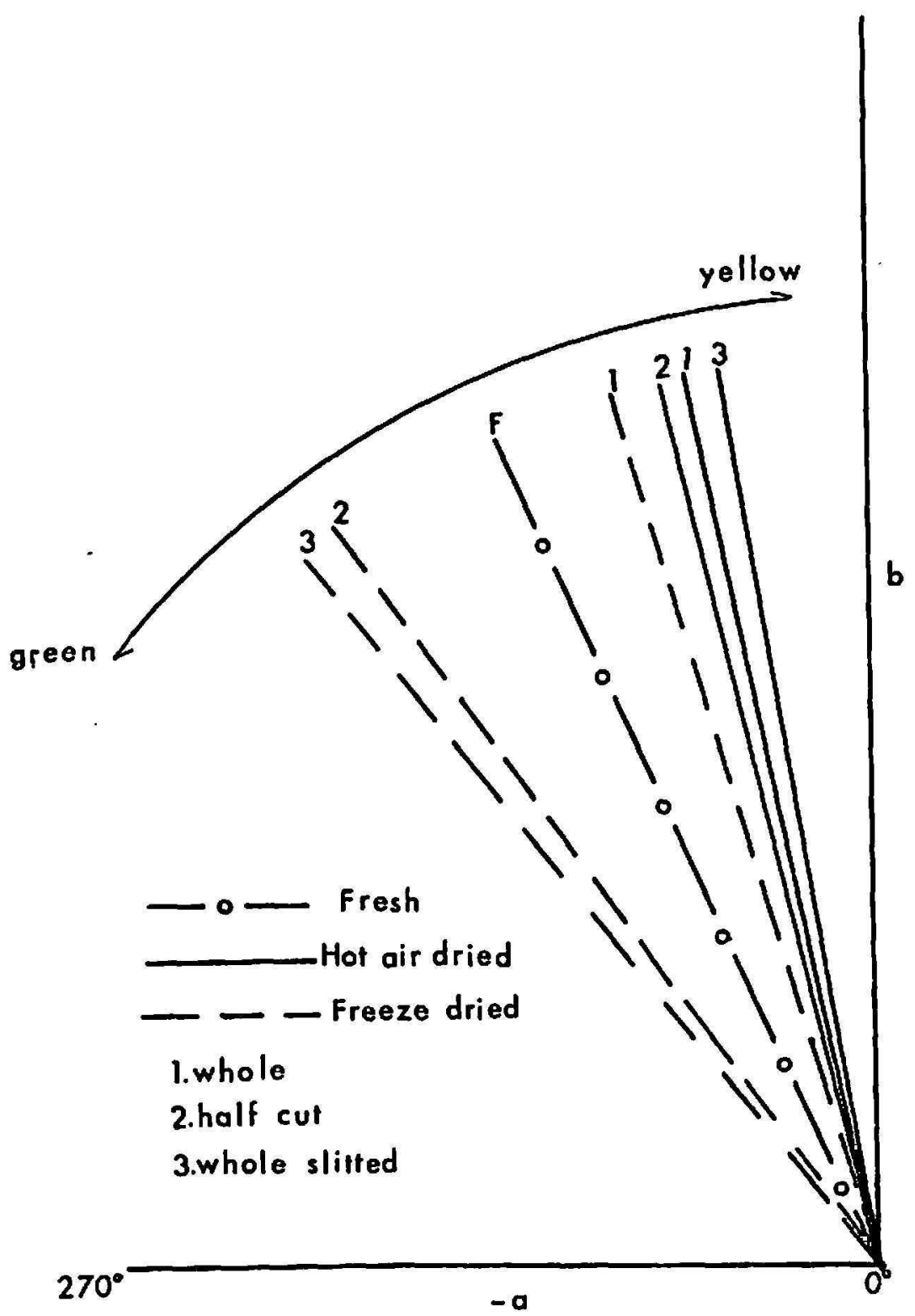

Fig. 2.-Effect of heat treatment on color of whole, half-cut, and whole-slitted sweet peppers during dehydration.

ing. Only half-cut or whole-slitted sweet peppers should be used for dehydration because of the tough, leathery skin. From an economical stand point, half-cut fruits should be used. Our studies verify the findings of Lantz (11) who claimed that slicing or slitting the pods of chili reduced drying time by half. 
EFFECT OF PLATEN TEMPERATURE ON DRYING RATE AND

QUALITY OF FREEZE-DRIED SWEET PEPPERS

In freeze-drying, the platen temperature is another parameter that affects the drying rate and quility of the end product.

Half-cut green peppers were freeze-dried using the platen temperature and drying time indicated in table 2 . The results obtained from these treatments also are indicated in this table.

These results show that when an initial platen temperature of $180^{\circ} \mathrm{F}$. is maintained for 2 hours and then lowered to $150^{\circ} \mathrm{F}$. for the rest of the drying period, a product of acceptable quality is obtained in a relatively short

TABLE 2.-Effect of different drying temperatures on drying rate and quality of freeze-dried sweet peppers

\begin{tabular}{|c|c|c|c|c|c|c|c|c|c|}
\hline \multirow{2}{*}{ Sample } & \multicolumn{4}{|c|}{ Heating conditions } & \multirow{2}{*}{$\begin{array}{c}\begin{array}{c}\text { Total } \\
\text { drying } \\
\text { time }\end{array} \\
\text { Hours }\end{array}$} & \multirow{2}{*}{$\begin{array}{l}\text { Moisture } \\
\text { Percent }\end{array}$} & \multicolumn{3}{|c|}{ Hunter color } \\
\hline & $\begin{array}{l}\text { Initial } \\
\text { platen } \\
\text { temper- } \\
\text { ature }\end{array}$ & $\begin{array}{l}\text { Time } \\
\text { in } \\
\text { bours }\end{array}$ & $\begin{array}{l}\text { Final } \\
\text { temper- } \\
\text { ature }\end{array}$ & 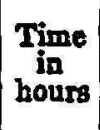 & & & $R d$ & $a$ & $b$ \\
\hline $\begin{array}{l}\text { Fresh sweet } \\
\text { peppers }\end{array}$ & ${ }^{\circ} \boldsymbol{F}$ & & ${ }^{\circ} \boldsymbol{P}$ & & & & 17.3 & -17.1 & +22.1 \\
\hline $\begin{array}{l}\text { Dehydrated sweet } \\
\text { peppers }\end{array}$ & $180^{\circ}$ & 6132 & & & $61 / 2$ & 3.17 & 43.1 & -13.3 & +21.9 \\
\hline Do & $180^{\circ}$ & $71 / 4$ & & & $71 / 4$ & - & 8.5 & -8.1 & +15.4 \\
\hline Do & $180^{\circ}$ & 3 & 150 & 4 & 7 & 3.00 & 41.0 & -15.0 & +24.9 \\
\hline Do & $180^{\circ}$ & 3 & 150 & 3 & 6 & 2.43 & 42.8 & -16.0 & +23.4 \\
\hline Do & $180^{\circ}$ & 2 & 150 & 6 & 8 & 3.00 & 42.5 & -19.5 & +23.5 \\
\hline Do & $180^{\circ}$ & $13 / 2$ & 150 & $61 / 2$ & 8 & 6.24 & 38.1 & -13.9 & +22.3 \\
\hline Do & $200^{\circ}$ & $41 / 2$ & & & $41 / 2$ & 2.89 & 4.24 & -12.4 & +21.6 \\
\hline
\end{tabular}

period of time. When initial platen temperatures above $180^{\circ} \mathrm{F}$. were used, although the drying rate was increased, a destruction of the green color was observed and darkening of the tissue resulted.

Drying curves for the different treatments used are shown in figure 3. As expected, the rate of drying was faster at the higher temperatures. With an initial platen temperature of $180^{\circ} \mathrm{F}$, the rate of drying was dependent on the length of time during which the platen temperature was maintained at this high level. Maintaining the platen temperature at $180^{\circ} \mathrm{F}$. for 2 hours followed by a temperature of $150^{\circ} \mathrm{F}$. for the rest of the cycle, proved to be satisfactory. Under these conditions, the proper rate of drying is attained and the quality of the end product is satisfactory. 


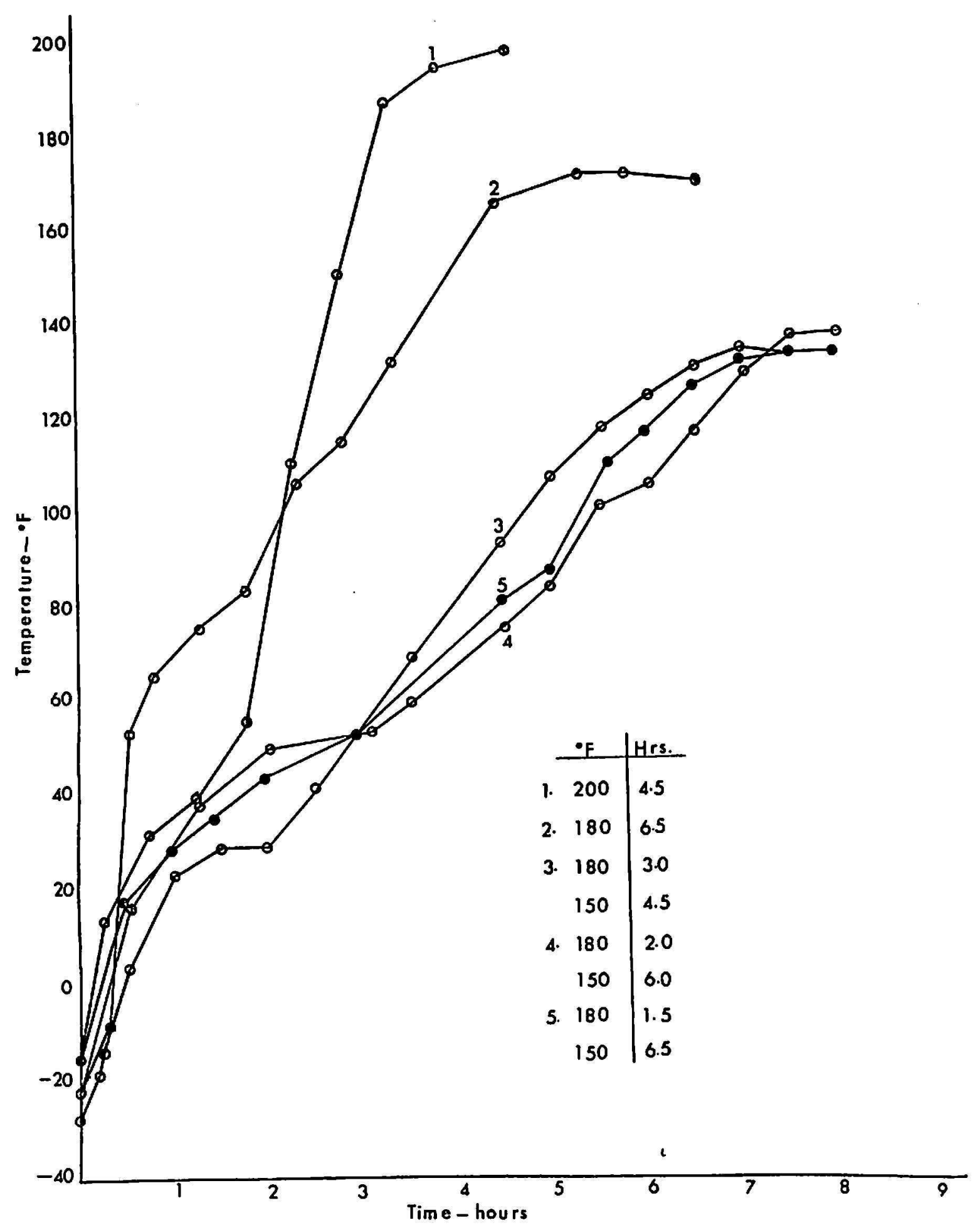

Fra. 3.-Freeze-drying curves for sweet peppers at different platen temperatures.

\section{DRYING TTME}

The experiments discussed so far indicate the best drying conditions are obtained for freeze-drying sweet peppers when the half-cut fruits are dehydrated using an initial platen temperature of $180^{\circ} \mathrm{F}$. during 2 hours, and 
then reducing to $150^{\circ} \mathrm{F}$. during the rest of the drying period. To predict the total drying time for sweet peppers under these conditions, samples were taken at frequent intervals and analyzed for moisture content and color retention during the freeze-drying cycle.

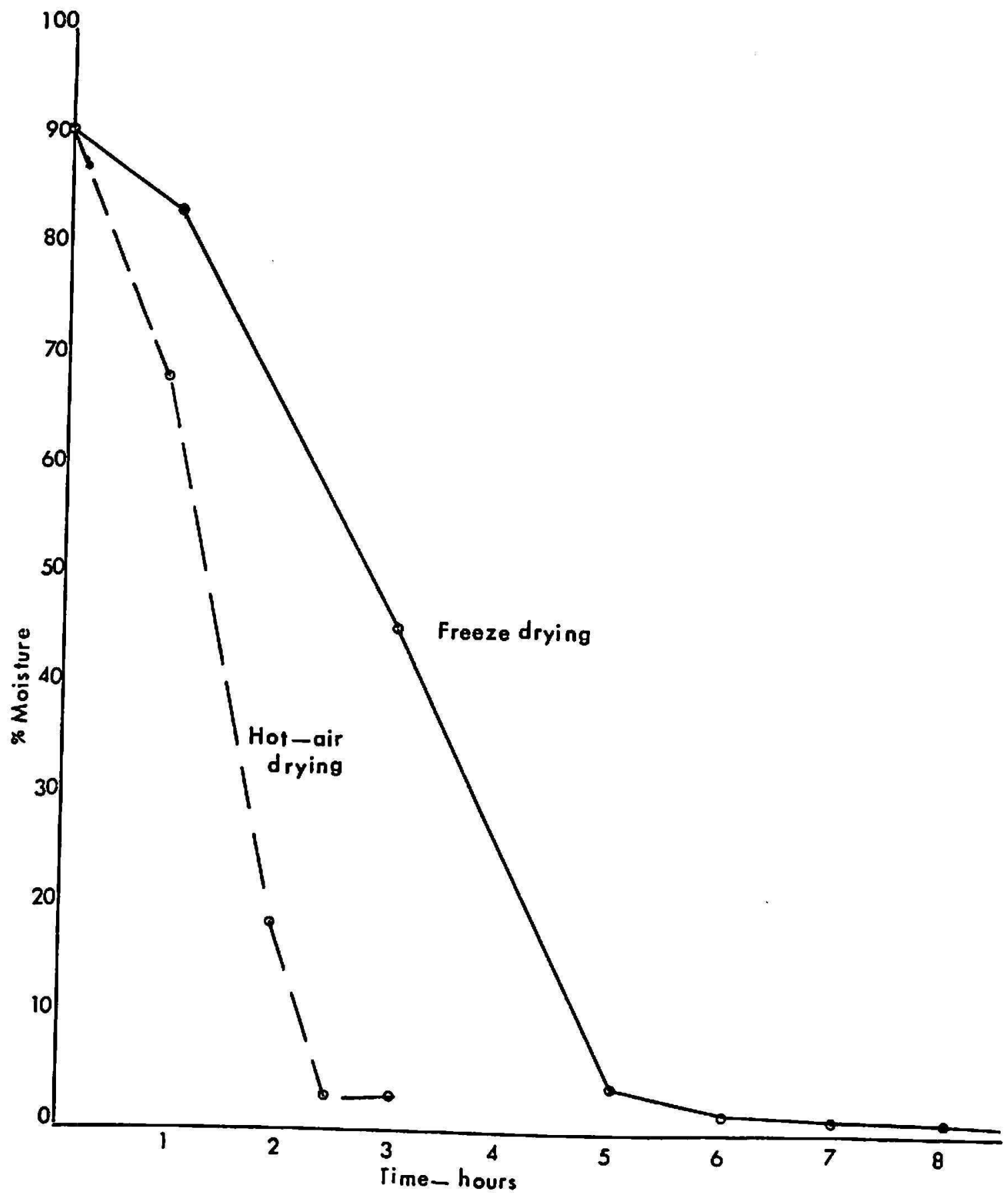

FIG. 4.-Dehydration rates for sweet peppers during hot-air and freeze-drying.

The changes in moisture content of half-cut sweet peppers during a drying cycle of 8.5 hours are indicated in figure 4 . These results indicate that when an initial platen temperature of $180^{\circ} \mathrm{F}$. is used during 2 hours and 
then lowered to $150^{\circ} \mathrm{F}$., the samples were dehydrated to the desired moisture content in a 6 to 7 hour cycle. Changes in moisture content of the sweet peppers while being hot-air dried at $165^{\circ} \mathrm{F}$. are also shown in this figure. The maximum time for drying peppers in hot air is taken as that time at which the product is no longer pliable and cracks when bent. The

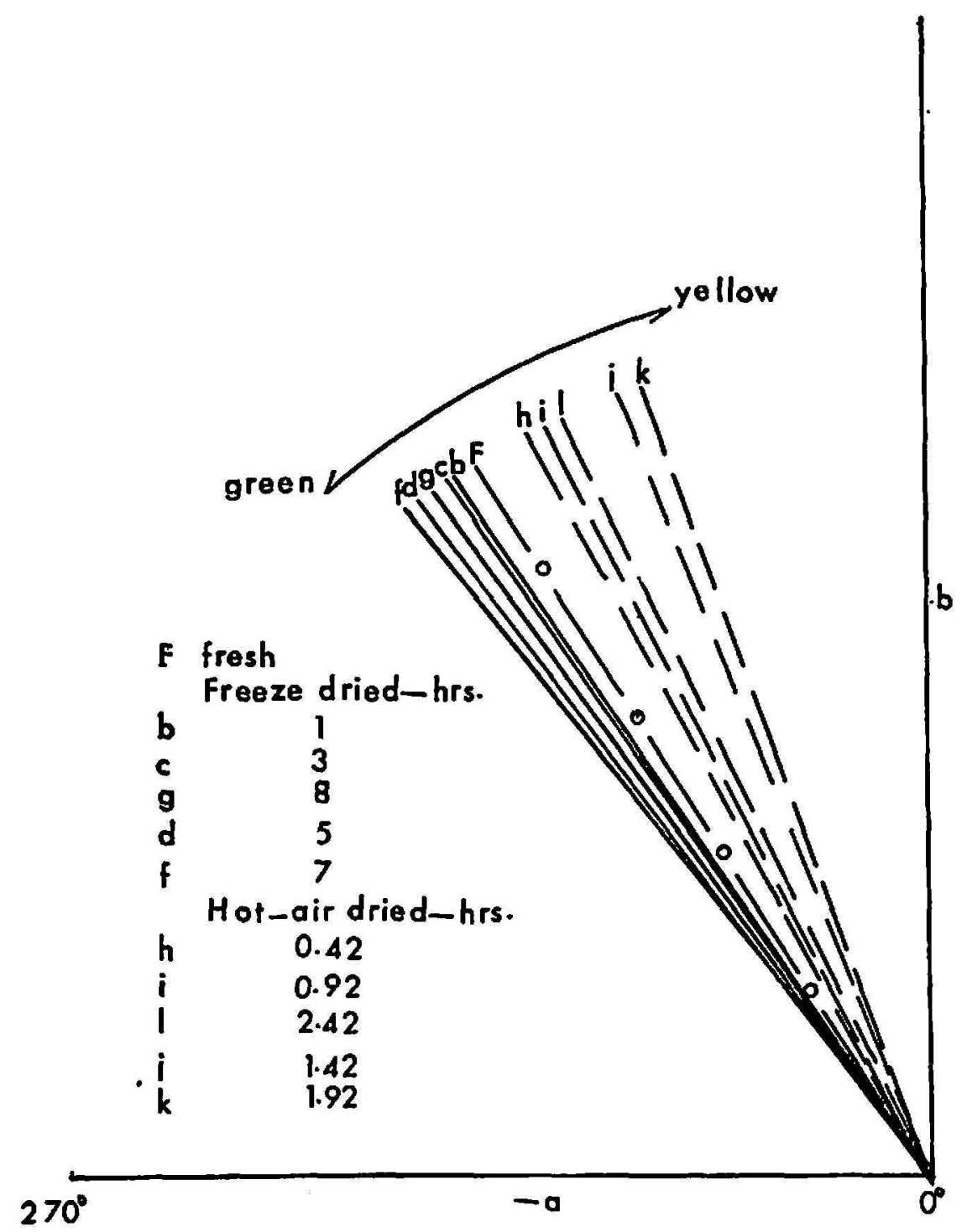

FrG. 5.-Effect of heat treatment on color of sweet peppers during hot-air and freeze-drying cycles.

results obtained indicate that such a condition is reached after 2.5 hours. The moisture content at this point was about 3.0 percent.

The variation in color of the sweet peppers during the drying cycle are shown in figure 5. The values for $\tan -1 a / b$ are shown in this graph for both the hot-air and freeze-dried samples. The progressive destruction of the green color is noted in the graph during the hot-air drying cycle while concentration of green pigment is noted during the freeze-drying cycle. 


\section{INACTIVATION OF THE ENZYME BYSTHM PRIOR TO FREEZE-DRYING}

It generally is accepted that low moisture content of a dehydrated product is a safeguard against subsequent enzymatic deterioration during storage. For this reason, many types of foods are dehydrated without a preliminary enzyme inactivation.

Recent research with enzymes indicates there is some enzyme activity in food with a very low moisture content. Studies were conducted to determine the role that enzymes play in the deterioration of the quality of freeze-dried sweet peppers during storage.

For the inactivation of the enzymes system in fresh sweet peppers, hot water and steam were tried. Steam blanching for 1.5 minutes proved to be

TABLE 3.-Moisiure content and color of blanched and unblanched freeze-dried sweet peppers

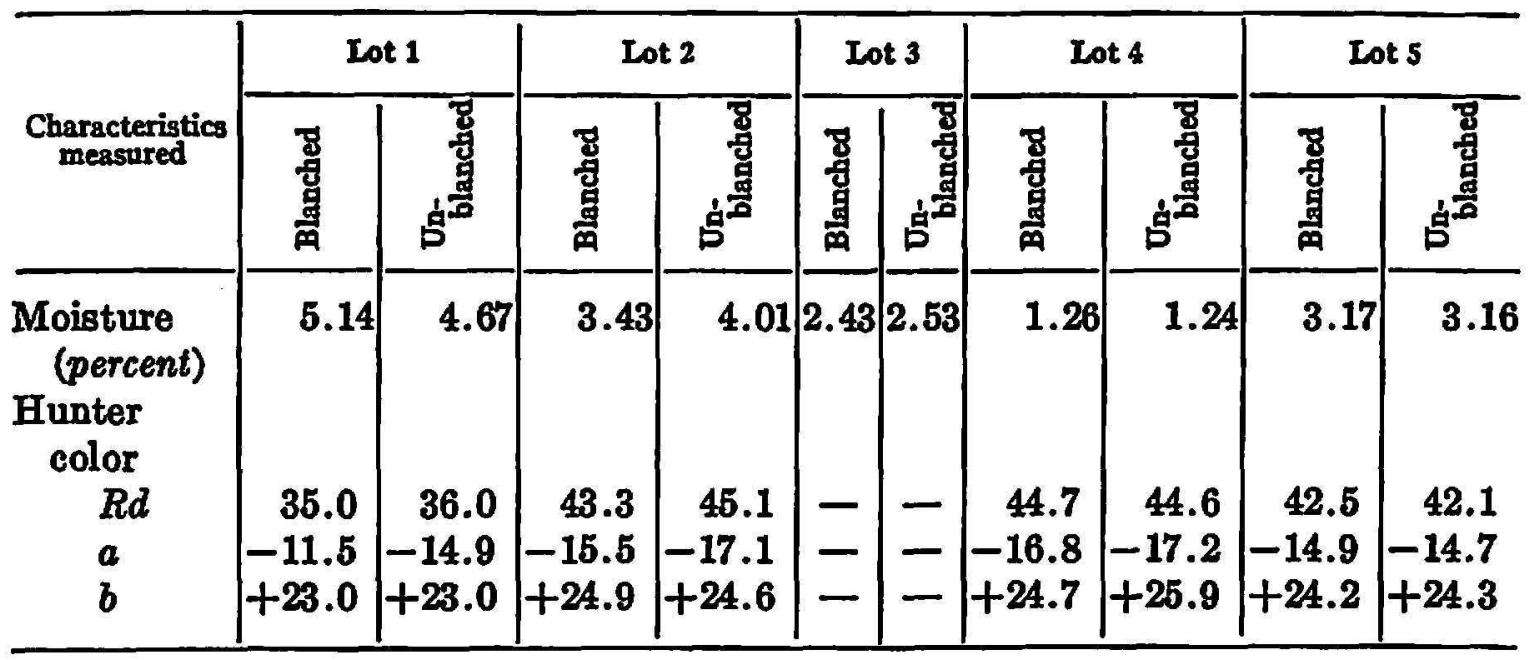

the best treatment because the half-cut peppers retained their shape and no seeds were lost. The peroxidase test was used as an index of inactivation.

Color was determined in blanched and unblanched samples. The moisture content and color of the freeze-dried samples are given in table 3. No appreciable change in the color was observed in any of the samples after drying or during storage. Blanching had no appreciable effect on the heat penetration, drying time, nor on the final moisture content of the product.

THE FEFECT OF BEVERAL TREATMENTS ON THE MICROBIAL COUNT

The microbial counts for unwashed, tap-water washed, washed and blanched, and freeze-dried blanched and unblanched peppers are given in table 4. The results show a reduction in plate counts for bacteria, yeasts, and molds by washing, and their complete destruction by steam blanching. 
A survival of bacteria was observed during freeze-drying of unblanched samples. These results are similar to those of Sinskey et al. (19) and Saleh et al. (20) who reported that the natural flora of some foods is capable of surviving freeze-drying.

TABLE 4.-Microbial examination of sweet peppers

\begin{tabular}{l|c|c|c}
\hline \multirow{2}{*}{$\begin{array}{c}\text { Condition of sweet } \\
\text { peppers examined }\end{array}$} & \multicolumn{2}{|c}{ Average number indicated microorganisms per gram } \\
\cline { 2 - 4 } & Bacteria & Yeasts & Molds \\
\hline A-Fresh green sweet peppers: & & & \\
1-Unwashed & $19 \times 10^{8}$ & $11 \times 10^{8}$ & $81 \times 10^{3}$ \\
2-Tapwater washed & $8 \times 10^{8}$ & $5 \times 10^{8}$ & $5 \times 10^{3}$ \\
3-Washed and steam treated & 0 & 0 & 0 \\
B-Freeze dried sweet peppers: & $50 \times 10^{3}$ & 0 & 0 \\
1-Unblanched & 0 & 0 & 0 \\
2-Steam treated & & 0 & 0 \\
\hline
\end{tabular}

TABLE 5.-Effect of storage on the color of freeze-dried sweet peppers packed in enamel

\begin{tabular}{|c|c|c|c|c|c|c|c|c|}
\hline \multirow{2}{*}{ Sample } & \multirow{2}{*}{$\begin{array}{l}\text { Days in } \\
\text { storage }\end{array}$} & \multirow{2}{*}{$\begin{array}{c}\text { Initial } \\
\text { moisture } \\
\text { content }\end{array}$} & \multicolumn{6}{|c|}{ Color of freeze-dried sweet peppers packed in } \\
\hline & & & \multicolumn{3}{|c|}{ Enamel cans } & \multicolumn{3}{|c|}{ Glass jars } \\
\hline & & Percent & $R d$ & $a$ & $b$ & $R d$ & a & $b$ \\
\hline 1 & $\begin{array}{r}1 \\
35 \\
81 \\
301\end{array}$ & 5.62 & $\begin{array}{l}36.2 \\
34.0 \\
37.8 \\
39.7\end{array}$ & $\begin{array}{l}-17.3 \\
-14.7 \\
-14.1 \\
-17.3\end{array}$ & $\begin{array}{l}+22.9 \\
+22.1 \\
+21.9 \\
+22.4\end{array}$ & $\begin{array}{c}38.9 \\
37.3 \\
- \\
42.2\end{array}$ & $\begin{array}{c}-18.2 \\
-17.5 \\
-\overline{16.3}\end{array}$ & $\begin{array}{r}+22.9 \\
+22.9 \\
-\overline{21} .0\end{array}$ \\
\hline 2 & $\begin{array}{r}1 \\
22 \\
67\end{array}$ & 8.52 & $\begin{array}{l}34.0 \\
33.0 \\
34.0\end{array}$ & $\begin{array}{l}-18.2 \\
-15.7 \\
-12.0\end{array}$ & $\begin{array}{l}+23.0 \\
+21.7 \\
+21.2\end{array}$ & $\begin{array}{c}37.2 \\
32.6 \\
-\end{array}$ & $\begin{array}{c}-18.8 \\
-14.7 \\
-\end{array}$ & $\begin{array}{c}+23.0 \\
+22.2 \\
-\end{array}$ \\
\hline 3 & $\begin{array}{r}6 \\
15 \\
60 \\
286\end{array}$ & 2.60 & $\begin{array}{l}42.5 \\
41.1 \\
41.9 \\
42.9\end{array}$ & $\begin{array}{l}-19.5 \\
-19.3 \\
-17.0 \\
-15.0\end{array}$ & $\begin{array}{r}+23.3 \\
+22.8 \\
+22.1 \\
+22.5\end{array}$ & $\begin{array}{c}42.0 \\
41.3 \\
- \\
40.2\end{array}$ & $\begin{array}{c}-19.5 \\
-18.5 \\
-\overline{16.2}\end{array}$ & $\begin{array}{r}+23.0 \\
+22.6 \\
-\overline{22} .6\end{array}$ \\
\hline
\end{tabular}

\section{BEFECT OF PACKAGING ON SHELF-LIFE}

Freeze-dried, unblanched sweet peppers with different moisture content were packed in glass jars and in cans under atmospheric conditions. Samples were analyzed at frequent intervals for color determination and moisture. The results, shown in table 5, do not indicate any appreciable change in the green color of the samples with a moisture content between 2.60 and 
5.62 percent. In the sample with a moisture content of 8.5 percent, complete degradation of the green color and development of a very unpleasant odor occurred in both types of containers after 67 days in storage.

This deterioration may be due to a non-enzymatic browning, which limits the storage life of freeze-dried foods. This reaction results in darkening, deterioration of color, and development of undesirable off-flavors. The chief method of preventing this type of deterioration is to dry to an extremely low moisture content. The moisture levels required for adequate stability vary with the type of product (16). In the case of the green peppers studied, a moisture content ranging from 2.60 to 5.62 percent seems adequate.

The stability of the hot-air dried samples was inferior to that of the freezedried product under similar conditions of storage. A progressive deteriora-

TABLE 6.-Effect of storage on the color of freeze-dried and hot-air dried sweet peppers packed in glass jars

\begin{tabular}{|c|c|c|c|c|c|c|c|c|c|c|}
\hline \multirow{2}{*}{$\begin{array}{c}\text { Days in } \\
\text { storrage at } \\
85^{\circ} \mathrm{F}+\end{array}$} & \multicolumn{5}{|c|}{ Freeze-dried } & \multicolumn{5}{|c|}{ Hot-air dried } \\
\hline & \multicolumn{3}{|c|}{ Color } & $\begin{array}{l}\text { Mois- } \\
\text { ture }\end{array}$ & $\begin{array}{l}\text { Ether } \\
\text { extract }\end{array}$ & \multicolumn{3}{|c|}{ Color } & $\begin{array}{c}\text { Mois- } \\
\text { ture }\end{array}$ & $\begin{array}{l}\text { Ether } \\
\text { extract }\end{array}$ \\
\hline & $\boldsymbol{R d}$ & $a$ & $b$ & Percent & Percent & $R d$ & 0 & $b$ & Percent & Percens \\
\hline 2 & 36.8 & -17.5 & +23.4 & 3.09 & - & 21.0 & -6.5 & +20.1 & 7.17 & - \\
\hline 20 & 39.1 & -18.3 & +22.2 & & 4.47 & 24.1 & -8.3 & +20.1 & & 4.57 \\
\hline 30 & 36.8 & -16.5 & +22.0 & & 3.04 & 19.1 & -5.6 & +18.5 & & 3.03 \\
\hline 365 & 34.0 & -15.1 & +20.2 & & 3.65 & 10.6 & -2.2 & +15.5 & & 3.27 \\
\hline 730 & 20.4 & -9.6 & +21.1 & & - & 8.4 & -1.0 & +14.7 & & - \\
\hline
\end{tabular}

tion of color, shown in table 6, was observed in the hot-air dried sweet peppers. These results do not agree with the reports of Wuhrmann et al. (2S) who indicate that the storage stability of freeze-dried vegetables under an oxygen-containing atmosphere may not be superior to those delydrated conventionally, and with those of Mackinney et al. (24) who report that freeze-dried carrots are less stable under various storage conditions than those dried conventionally. Our results, however, are in agreement with those of Wuhrman et al. (2S), who indicate that fruits dried by sublimation are more resistant to storage destruction than dried fruits.

\section{DISCUSSION AND CONCLUSIONS}

To determine the quality of dehydrated sweet peppers, several indices were studied such as changes in color, pungency retention and the percentages of ether extract and volatile oils. The results obtained indicate that percent ether extract and volatile oils can not be used as an index of quality, because no appreciable changes can be determined when the sam- 
ples are submitted to a severe treatment as hot-air drying, or to a mild treatment as freeze-drying. No changes were observed in either samples during storage.

Sweet peppers are very mild pungent fruits, thus highly sensitive tests and trained tasters are needed to determine the rate of pungency in fresh and dried fruits. We were not successful in using the Scoville rating (10) or the Zuzuki et al. (9) method to determine the rate of pungency in fresh sweet peppers.

The observations made with sweet peppers indicate there is a gradual deterioration in color, pungency, and flavor during the process of hot-air drying and in the dried samples during storage. Negligible changes in color, pungency, and flavor were observed during freeze-drying and storage of the freeze-dried samples.

When the color changes were determined, using the Hunter Color and Color Difference Meter, similar results were obtained. A progressive color deterioration was measured in the sweet peppers during the hot-air drying process and during storage of the resulting dried samples. No appreciable color changes were measured in the freeze-dried samples during freezedrying or storage.

In all these studies it was observed that a deterioration in flavor and aroma of sweet peppers during dehydration and storage is always accompanied by a deterioration of the green color. Although further work needs to be done in the evaluation of the quality of fresh and dehydrated sweet peppers, it may be concluded that changes in color of dehydrated sweet peppers as measured in the Hunter Color Meter can be used as an index of quality. These conclusions agree with those of Wuhrmann et al. (2S) who indicate that the deterioration of dehydrated vegetables is characterized bv development of off-flavor and color.

\section{SUMMARY}

Studies were conducted to dehydrate garden sweet peppers by means of hot-air and freeze-drying.

Sweet peppers have tough, leathery skins which makes escape of moisture difficult and prolongs drying time. Our data indicates that dehydration of half-cut or slitted fruit is accomplished either by conventional hot-air or by freeze-drying in reasonably shorter periods of time than whole fruit.

Change in color or shape was not observed in sweet peppers during freezedrying. Great deterioration in the green color was observed in the samples dehydrated with hot-air at $165^{\circ} \mathrm{F}$. The shelf-life of the freeze-dried product is superior to that of the conventionally hot-air dried product.

For freeze-drying the sweet peppers within a reasonable period of time, and to obtain a product with shape and color similar to the fresh fruit, a 
platen temperature of $180^{\circ} \mathrm{F}$. should be used during 2 hours and then reduced to $150^{\circ} \mathrm{F}$. during the rest of the drying period.

Heat treatment to inactivate microbial activity of sweet peppers prior to freeze-drying greatly reduces the microbial count and does not affect the drying rate, quality and shelf-life of the end product.

Deterioration of sweet peppers during drying and storage is characterized by development of off-flavor and color. Because the measurement of off-flavor is difficult in a mild pungent fruit such as sweet peppers, these studies indicate that measurement of changes in color can be used as an index of quality.

\section{RESUMEN}

Se ha estudiado la forma de deshidratar los ajíes dulces por medio de liofilización y del método convencional con aire caliente.

Los ajies dulces tienen una cutícula o piel superficial semi-impermeable que dificulta la evaporación del agua durante el proceso de la deshidratación. Para determinar la forma más adecuada de secar estos ajíes mediante los métodos ya mencionados, se usaron frutas enteras, partidas en mitades y enteras con la piel rayada. Los resultados obtenidos de estos estudios indican que cuando se usan ajíes con la piel rayada y cortados en mitades, el tiempo del secado se reduce grandemente y el producto final es de mejor calidad que cuando se usan ajíes enteros.

El color, apariencia general, aroma y vida en almacén de los ajís dulces liofilizados son superiores a los de los que se secan con aire caliente.

Para liofilizar los ajfes dulces en un tiempo razonable, a la vez que se obtenga un producto de forma y color similar al producto fresco, debe usars una temperatura inicial de $180^{\circ} \mathrm{F}$. durante 2 horas, seguido esto de una temperatura de $150^{\circ} \mathrm{F}$. durante el resto del periodo del secado.

El tratamiento con calor para la inactivación de las enzimas no afecta la razón del secado, la calidad ni la vida en almacén del producto final, pero reduce grandemente el número de microbios.

El deterioro de los ajies dulces durante el secado y luego del producto deshidratado, se ha caracterizado por el desarrollo de sabores extraños y deterioro del color. El poder medir los sabores extraños en una fruta levemente picante es dificil. Los resultados obtenidos en este trabajo indican que puede usarse como índice de calidad el cambio de color del producto secado.

\section{LITERATURE CITED}

1. Parry, J. W., Spices, Their Morphology, Histology and Chemistry, Chemical Publishing Co. Inc., New York, N. Y., 1962.

2. Parry, J. W., The Spice Handbook, Chemical Publishing Co., New York, N. Y. 1945.

3. Erwing, A. T., The Peppers, Bull. 293, Iowa Agr. Expt. Sta., 1932. 
4. Boswell, V. R., Commercial cabbage culture, Circ. 252, USDA, Wash., D. C., 1945.

5. Lease, J. G., and Lease, E. J., Effect of drying conditions on initial color, color retention and pungence of red peppers, Food Technol., 16 (11): 104-6, 1962.

6. Lease, J. G., and Lease, E. J., Factors affecting the retention of red color in peppers, Food Technol. 10 (8): 368-73, 1956.

7. Moster, J. B., and Prater, A. N., Color of Capsicum spices, I. Measurement of extractable color, Food Technol. 6 (12), 1952.

8. Moster, J. B., and Prater, A. N., Color of Capsicum spices, II. Extraction of color, Food Technol. 11 (3), 1957.

9. Zuzuki, J. I., Tousing, F., and Morse, R. E., Some observations on red pepper, I. A new method for the determination of pungency in red peppers, Food Technol. 11 (2): 100-3, 1957.

10. Wirth, E. H., and Gathercoal, E. N., Report of the Scoville organoleptic method for the evaluation of Capsicum, J. Am. Pharm. Assoc. 1s: 217-9, 1924.

11. Lantz, E. M., Effects of canning and drying on the carotene and ascorbic acid content of Chili, Bull. 327, N. Mex. Agr. Expt. Sta., 1946.

12. Daoud, H. N., and Luh, B. S., Packaging of foods in laminated and aluminum-film combination pouches, IV. Freeze-dried red bell peppers, Food Technol. 21 (3A): 21A-25A, 1967.

13. Ryan, J. W., Food freeze-drying, Food Technol. 19 (4): 480-3, 1965.

14. Goldblith, S. A., Karel, M., and Lusk, G., Freeze dehydration of food, Food Technol. 17 (3): 258-63, 1963.

15. Larson, R. W., Steimberg, M. P., and Nelson, A. I., Effect of gas flushing at several pressures on rate of freeze-drying of beef, Food Technol. 21 (3A): 83A87A, 1967.

16. Goldblith, S. A., Karel, M., and Lusk, G., Freeze-dehydration of food, Food Technol. 17 (2): 139-44, 1963.

17. Lusk, G., Karel, M., and Goldblith, S. A., Effect of some processing parameters on the rate of freeze-drying of shrimp, Food Technol. 21 (4): 620-2, 1965.

18. Draudt, H. N., Damon, C. E., Huany, I. Y., and Chang, M. T., Enzyme activity on freeze-dried foods, Purdue Univ., Contr. Res. Proj., Rept. No. 7-48-06, 031A, 19, Feb., 1961.

19. Sinskey, T. J., Mc Intosh, A. H., Pablo, I. S., Silverman, G. J., Goldblith, S. A., Considerations on the recovery of microorganisms from freeze-dried foods, Health Lab. Sci. 1, 1964.

20. Saleh, B. A., Silverman, G. I., and Goldblith, S. A., Microbial evaluation of freeze-dried foods, Food Technol. 20 (5): 671-4, 1966.

21. Taylor, T. C., Packaging of freeze-dried, Food Eng. $S 3$ (9): 44, 1961.

22. Foda, Y. H., and EI-Waraki, A., Effect of dehydration, freeze-drying and packaging on the quality of green beans, Food Technol. 21 (7): 1021-4, 1967.

23. Wuhrmann, J. J., Simone, M., and Chichester, C. O., The storage stability of freeze-dried soup mixes, Food Technol. 13 (1): 36-40, 1959.

24. Mackinney, G., Lukton, A., and Greenbaus, L., Carotenoid stability in stored dehydrated carrots, Food Technol. 12 (1): 1958.

25. Association of Official Agricultural Chemists, Official Methods of Analysis, 9th ed., Wash., D. C., 1960. 